University of Pennsylvania Carey Law School

Penn Law: Legal Scholarship Repository

Faculty Scholarship at Penn Law

4-8-2014

\title{
Murder Mitigation in the Fifty-Two American Jurisdictions: A Case Study in Doctrinal Interrelation Analysis
}

Paul H. Robinson

University of Pennsylvania Carey Law School

Follow this and additional works at: https://scholarship.law.upenn.edu/faculty_scholarship

Part of the Cognition and Perception Commons, Criminal Law Commons, Criminology Commons, Criminology and Criminal Justice Commons, Law Enforcement and Corrections Commons, Public Law and Legal Theory Commons, and the Social Control, Law, Crime, and Deviance Commons

\section{Repository Citation}

Robinson, Paul H., "Murder Mitigation in the Fifty-Two American Jurisdictions: A Case Study in Doctrinal Interrelation Analysis" (2014). Faculty Scholarship at Penn Law. 1191.

https://scholarship.law.upenn.edu/faculty_scholarship/1191

This Article is brought to you for free and open access by Penn Law: Legal Scholarship Repository. It has been accepted for inclusion in Faculty Scholarship at Penn Law by an authorized administrator of Penn Law: Legal Scholarship Repository. For more information, please contact PennlawIR@law.upenn.edu. 


\title{
MURDER MITIGATION IN THE FIFTY-TWO AMERICAN JURISDICTIONS: A CASE STUDY IN DOCTRINAL INTERRELATION ANALYSIS
}

\author{
Paul H. Robinson*
}

Abstract

This Essay surveys the law in the fifty-two American jurisdictions with regard to the three doctrines that commonly provide a mitigation or defense to murder liability: common-law provocation and its modern counterpart, extreme mental or emotional disturbance; the so-called diminished capacity defense and its modern counterpart, mental illness negating an offense element; and the insanity defense. The essay then examines the patterns among the jurisdictions in the particular formulation they adopt for the three doctrines and the combinations in which those formulations commonly appear in different jurisdictions. After this review, the essay steps back to see what kinds of general conclusions can be drawn from the patterns that the survey reveals. The methodology offers a case study in the kinds of insights to be gained from such doctrinal interrelation analysis: insights about not only the doctrines at hand, but also about the lawmaking process that produced them.

I. THE DOCTRINES \& THEIR POPULARITY......................................... 20

A. A Survey of American Jurisdictions .................................... 21

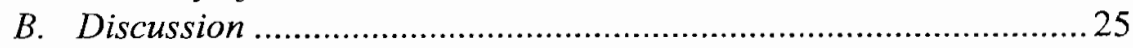

II. THE INTERRELATION AMONG THE DOCTRINES ...............................26

A. Insanity and MINOE .................................................. 28

B. Insanity and Provocation/EMED (Extreme Mental or Emotional Disturbance) ..................................................................... 29

C. MINOE and Provocation/EMED (Extreme Mental or Emotional Disturbance) ..................................................................... 30

D. States Sharing the Same Approach to All Three Doctrines ........... 31

III. CONCLUSION ......................................................................... 34

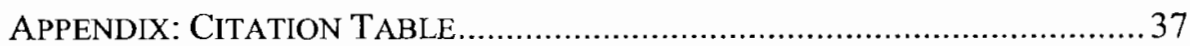

Three doctrines operate to provide mental- or emotional-based mitigations or excuses in homicide cases. First, the common-law provocation mitigation

* Colin S. Diver Professor of Law, University of Pennsylvania. The author wishes to acknowledge the excellent research assistance of Camber Stoddard and Brandon Kenney and to thank Robert Weisberg for his insight on the potential of doctrinal interrelation analysis. 
reduces murder to manslaughter, as does its broader modern incarnation, the mitigation for extreme mental or emotional disturbance (EMED). ${ }^{1}$ Second, the "diminished capacity" defense can provide a mitigation or, in some jurisdictions, a complete defense, if the offender's mental illness negates-makes it impossible to prove that the offender had-a required offense culpability element. ${ }^{2}$ This doctrine is also referred to, more accurately and usefully, as mental illness negating an offense element (MINOE). ${ }^{3}$ Finally, the insanity defense can provide a complete excuse depending upon the effects of an offender's mental illness at the time of the offense. ${ }^{4}$

This brief Essay reviews these doctrines, their various formulations, and their adoption in the fifty-two American jurisdictions. ${ }^{5}$ One goal is to get a clear view of the legal landscape in the area. With fifty-two jurisdictions, too many of us are left to guess or to rely upon the existing common wisdom on the issue. Beyond that, however, the study introduces a methodology that might be useful in a variety of contexts: comparing the pattern of interrelation of a doctrine's adoption in different states and the pattern of adoption of different but related doctrines within the same state. ${ }^{6}$ The approach has the potential to tell us not only something about the doctrines at hand, but also something about the lawmaking process that produced them.

\section{THE DOCTRINES \& THEIR POPULARITY}

Each of the three doctrines appears in a variety of formulations in the states. The analysis in Part I reviews the approach of each state on each doctrine and groups together states with similar approaches. ${ }^{7}$ In the three tables below, the first column summarizes the various approaches, arranged from the narrowest at the bottom to the broadest at the top (broadest in the sense of providing a mitigation or excuse to the greatest number of cases). The second column in each table describes the kinds of cases that are added by the category over the more-narrow category immediately below it. So, for example, Table 1 's row 4 adds control impairment to the scope of the defense in row 3 . The final column, on the far right of each table, identifies the states that take that approach. Each category groups together formulations of similar overall effect, although the formulations may be different in many minor respects. The table

1. See sources cited infra Appendix Table, column 4.

2. See sources cited infra Appendix Table, column 3.

3. PAUl H. ROBINSON, Abnormal Mental State Mitigations of Murder-the U.S. Perspective, in LoSS OF CONTROL AND Diminished RESPONSIBILITY: DOMESTIC, COMPARATIVE AND INTERnATIONAL PERSPECTIVES 291, 296 (Alan Reed \& Michael Bohlander eds., 2011), available at http://papers.ssm.com/ sol3/papers.rfm?abstract id=1676801.

4. See sources cited infra Appendix Table, column 2.

5. These include the fifty states plus the District of Columbia and the federal system. See infra Appendix Table.

6. See infra Part II.A-D.

7. See infra Part I.A-B. 
categorizations are drawn from statutory and, where that is lacking, caselaw authorities, which are collected in the Citation Table in the Appendix.

\section{A. A Survey of American Jurisdictions}

As to the first doctrine, six states have abolished the general excuse of insanity. ${ }^{8}$ Twenty-one states follow the most common approach and recognize the defense, but with the most narrow formulation of the common-law M'Naghten test, which requires that the actor not know the nature of his conduct or that it is wrong. ${ }^{9}$ Eight more states and the federal system keep with this approach of allowing the defense only for a purely cognitive dysfunction, but broaden the test somewhat by allowing it if the actor could not fully "appreciate" the criminality of his conduct, an approach taken from the Model Penal Code's formulation of the cognitive prong for the defense. ${ }^{10}$ The remaining sixteen jurisdictions go beyond this to recognize some form of a control prong, which allows the defense even if an actor appreciates the criminality of his conduct but is unable to control it. ${ }^{11}$ This is the Model Penal

8. See, e.g., KAN. STAT. ANN. § 21-5209 (West 2014) ("It shall be a defense to a prosecution under any statute that the defendant, as a result of mental disease or defect, lacked the culpable mental state required as an element of the crime charged. Mental disease or defect is not otherwise a defense."); NEV. REV. STAT. ANN. $§ 174.035$ (West 2013) ("A defendant may plead not guilty, guilty, guilty but mentally ill or, with the consent of the court, nolo contendere. The court may refuse to accept a plea of guilty or guilty but mentally ill."); Finger v. State, 27 P.3d 66, 78 (Nev. 2001) (en banc) ("No act committed by a person while in a state of insanity or voluntary intoxication shall be deemed less criminal by reason of his condition, but whenever the actual existence of any particular purpose, motive or intent is a necessary element to constitute a particular species or degree of crime, the fact of his insanity or intoxication may be taken into consideration in determining the purpose, motive or intent.").

9. See, e.g., GA. CODE ANN. § 16-3-2 (West 2014) ("A person shall not be found guilty of a crime if, at the time of the act, omission, or negligence constituting the crime, the person did not have mental capacity to distinguish between right and wrong in relation to such act, omission, or negligence."); N.J. STAT. ANN. § 2C:4-1 (West 2014) ("A person is not criminally responsible for conduct if at the time of such conduct he was laboring under such a defect of reason, from disease of the mind as not to know the nature and quality of the act he was doing, or if he did know it, that he did not know what he was doing was wrong."); Price $v$. Commonwealth, 323 S.E.2d 106, 109 (Va. 1984); Herbin v. Commonwealth, 503 S.E.2d 226, 230 (Va. Ct. App. 1998) ("[T]he actual M'Naghten test for insanity, stated in the disjunctive, is the rule in Virginia."). Under the M'Naghten test "it must be clearly proved that, at the time of the committing of the act, the party accused was labouring under such a defect of reason, from disease of the mind, as not to know the nature and quality of the act he was doing; or, if he did know it, that he did not know he was doing what was wrong." Price, 323 S.E.2d at 109 (quoting M'Naghten Case, (1843) 8 Eng. Rep. 718 (P.C.) 722-23).

10. See, e.g., 18 U.S.C. $\S 17$ (a) (2013) ("It is an affirmative defense to a prosecution under any Federal statute that, at the time of the commission of the acts constituting the offense, the defendant, as a result of a severe mental disease or defect, was unable to appreciate the nature and quality or the wrongfulness of his acts. Mental disease or defect does not otherwise constitute a defense."); ALA. CODE § 13A-3-1(a) (2014) ("It is an affirmative defense to a prosecution for any crime that, at the time of the commission of the acts constituting the offense, the defendant, as a result of severe mental disease or defect, was unable to appreciate the nature and quality or wrongfuiness of his acts."); DEL. CODE ANN. tit. 11, § 401(a) (West 2007 \& Supp. 2012) ("In any prosecution for an offense, it is an affirmative defense that, at the time of the conduct charged, as a result of mental illness or serious mental disorder, the accused lacked substantial capacity to appreciate the wrongfulness of the accused's conduct.").

11. See, e.g., VT. STAT. ANN. tit. 13, $\$ 4801$ (a)(1) (West 2014) ("A person is not responsible for criminal conduct if at the time of the criminal conduct, as a result of mental illness or deficiency, he lacked 
Code approach. ${ }^{12}$ The table below shows the specific jurisdictions that are part of each group. ${ }^{13}$

Table 1. Insanity Formulations

\begin{tabular}{|c|c|c|}
\hline . Formulation & Added Breadth Over More Narrow & States \\
\hline Cognitive \& Control (4) & Control impairment & $\begin{array}{l}\text { AR, CT, DC, HI, KY, } \\
\text { MD, MA, MI, NH, } \\
\text { NM, OR, RI, VT, VA, } \\
\text { WV, WY, MPC }\end{array}$ \\
\hline $\begin{array}{l}\text { Al1-Cognitive Only (3) } \\
\text { (impairment sufficient) }\end{array}$ & $\begin{array}{l}\text { Does "know" but impaired } \\
\text { appreciation }\end{array}$ & $\begin{array}{l}\text { AL, AK, DE, Federal, } \\
\text { IL, IN, ME, NY, TN }\end{array}$ \\
\hline $\begin{array}{l}\text { M Naghten (2), } \\
\text { (cognitive only, } \\
\text { absolute required) }\end{array}$ & Does not know & $\begin{array}{c}\text { AZ, CA, CO, FL, GA, } \\
\text { IA, LA, MN, MS, MO, } \\
\text { NE, NJ, NC, OH, OK, } \\
\text { PA, SC, SD, TX, WA, } \\
\text { WI }\end{array}$ \\
\hline Aboltion (1) & - & $\begin{array}{c}\mathrm{ID}, \mathrm{KS}, \mathrm{MT}, \mathrm{NV}, \mathrm{ND}, \\
\mathrm{UT}\end{array}$ \\
\hline
\end{tabular}

As to the second doctrine, while it is often referred to as the "diminished capacity" or "partial insanity" defense, it is nothing of the sort. In fact, it is just the reverse: rather than providing a defense, in most jurisdictions it imputes to an actor a required offense culpability element that he does not in fact have by barring the introduction of mental illness evidence that would negate the required element. ${ }^{14}$ In sixteen states, no offense culpability element of any kind may be negated by evidence of mental illness. ${ }^{15}$ Thirteen states permit mental

substantial capacity either to appreciate the wrongfuiness of his conduct or to conform his conduct to the requirements of law."), amended by 2014 Vt. Laws No. 158 (H. 555); WYO. STAT. ANN. § 7-11-304(a) (West 2014) ("A person is not responsible for criminal conduct if at the time of such conduct as a result of mental disease or defect he or she lacks adequate capacity either to appreciate the criminality of his or her conduct or to conform his or her conduct to the requirements of law."); Howard v. United States, 954 A.2d 415, 420 (D.C. 2008) ("To establish a prima facie case of insanity, the defendant must present sufficient evidence to show that at the time of the criminal conduet, as a result of mental disease or defect, he lacked substantial capacity to recognize the wrongfulness of his act or to conform his conduct to the requirements of the law." (quoting Patton v. United States, 782 A.2d 305, 312 (D.C. 2001) (internal quotation marks omitted))).

12. MODEl PENAL CODE $§ 4.01$ (1962).

13. New Hampshire is included in the group with the broadest formulation but goes beyond the Model Penal Code approach to allow the defense whenever the offense is the product of the mental illness. See N.H. REv. STAT. ANN. §628:2 (2014); see also State v. Labranche, 942 A.2d 1284, 1286-87 (N.H. 2008) (interpreting the statute to allow a defense when defendants "suffered from a mental illness and that the crime charged was a product of that illness"). Virginia is included in the control-prong group ( 4 ) because, while it defines insanity using the M Naghten standard, it has a separate "irresistible impulse" defense that essentially adds a narrow control prong to the insanity defense. See Herbin, 503 S.E.2d at 230.

14. See infra notes $15-16$ and accompanying text.

15. See, e.g., State v. Mott, 931 P.2d 1046, 1050 (Ariz. 1997) (en banc) (“Arizona's criminal code was based on the Model Penal Code. The 1962 version of the Model Penal Code allowed the admission of '[e]vidence that the defendant suffered from a mental disease or defect . . . whenever it [was] relevant to prove that the defendant did or did not have a state of mind that is an element of the offense.' This section was written in recognition of the existence of 'degrees of mental disease or defect that fall short of that required for invoking the defense of irresponsibility, but that may be put in evidence as tending to show that 
illness to negate only a specific intent. ${ }^{16}$ Only twenty-three jurisdictions, a minority of the fifty-two, take the Model Penal Code approach of allowing mental illness evidence to negate any element. ${ }^{17}$ Here are the specific jurisdictions that take each approach.

the defendant lacked the specific mens rea required for the commission of the offense charged.' The legislature's decision not to adopt this section of the Model Penal Code evidences its rejection of the use of psychological testimony to challenge the mens rea element of a crime." (alterations in original) (citations omitted)); State v. Jones, 359 So. 2 d 95, 98 (La. 1978) ("Louisiana is among the minority of eleven states that still reject the defense [diminished responsibility] in all aspects. In Louisiana, a mental defect or disorder, short of legal insanity (i.e., the incapability to distinguish between right and wrong, La.R.S. 14:14), cannot serve to negate the specific intent and reduce the degree of the crime."); Gill v. State, 552 S.E.2d 26, 32 (S.C. 2001 ) ("The diminished capacity doctrine allows a defendant to offer evidence of his mental condition with respect to his capacity to achieve the mens rea required for the commission of the offense charged. In. particular, the defense may be invoked to negate specific intent, where such intent is an element of the offense charged. Diminished capacity differs from the insanity defense in that it may be raised by a defendant who has conceded to be legally sane. The trial judge did not err by refusing to charge diminished capacity because it is not recognized in South Carolina." (citations onitted)).

16. See, e.g., Anfinson v. State, 758 N.W.2d 496, 502 (Iowa 2008) ("The diminished responsibility defense allows a defendant to negate the specific intent element of a crime by demonstrating due to some mental defect she did not have the capacity to form that specific intent."); State v. Balderama, 2004-NMSC008,135 N.M. 329,88 P.3d 845 ("Thus, we conclude that evidence of the condition of the mind of the accused at the time of the crime may be introduced, not only for the purpose of proving the inability to deliberate, but also to prove that the conditions were such that Defendant did not in fact, at the time of the killing, form a deliberate intent to kill." (emphasis omitted)); Commonwealth v. Spotz, 47 A.3d 63, 90 (Pa. 2012) ("A diminished capacity defense does not exculpate the defendant from criminal liability entirely, but instead negates the element of specific intent."); State v. Amazeen, 526 A.2d 1268, 1271 (R.I. 1987) ("By adopting the diminished-capacity defense, we thus expanded the rule enunciated in Vanasse . . . to allow evidence that a defendant's mental capacity was diminished by reasons other than intoxication to negate the proof of specific intent required to convict a defendant of certain oftenses, if those offenses included lesser, general-intent crimes of which the defendant could be convicted instead. Hence, evidence of trauma or mental disease not quite amounting to legal insanity may now be introduced, as intoxication always could, to defend one charged with a specific-intent crime.").

17. See, e.g., AlASKA STAT. $\$ 12.47 .020$ (a) (2012) ("Evidence that the defendant suffered from a mental disease or defect is admissible whenever it is relevant to prove that the defendant did or did not have a culpable mental state which is an element of the crime."); HAW. REV. STAT. \$ 704-401 (West 2014) ("Evidence that the defendant was affected by a physical or mental disease, disorder, or defect is admissible whenever it is relevant to prove that the defendant did or did not have a state of mind that is required to establish an element of the offense."); State v. Messier, 497 A.2d 740, 743 (Vt. 1985) ("Evidence offered by a defendant to prove such a mental disease or defect may or may not also operate to disprove the existence of mental states, such as intent or premeditation, which might be essential elements of the crime."). 
Table 2. MINOE Formulations

\begin{tabular}{|c|c|c|}
\hline Formulation & Added Breadth Over More Narrow & States \\
\hline Negate Any Element (3) & Negate knowing, reckless, or & Federal, HI, ID, IN, KS, \\
& negligent & ME, MD, MO, MT, NV, \\
& & NH, NJ, OH, OR, TN, \\
& & UT, VT, WA, WV, MPC \\
\cline { 2 - 3 } & & CA, IA, KY, MA, NE, \\
Negate Only litent (2) & Negate intent (or premeditation) & NY, NC, ND, NM, PA, \\
& & RI, SD, WY \\
\hline Cannot Negate Any & & AL, AZ, DE, DC, FL, \\
Element (1) & & GA, IL, LA, MN, MI, \\
& & MS, OK, SC, TX, VA, \\
& & WI \\
\hline
\end{tabular}

As to the third doctrine, a large majority of jurisdictions - forty of the fifty-two reject the Model Penal Code's attempt to broaden the common-law provocation defense, which typically mitigates murder to manslaughter. ${ }^{18}$ The remaining dozen states adopt the third doctrine by statutory formulation based upon the Model Penal Code-giving a mitigation for a killing under "extreme mental or emotional disturbance" 19 -although eight of those states drop the reference to "mental" and look only to "emotional disturbance." 20 Here are the specific jurisdictions.

18. See, e.g., IOWA CODE ANN. \$ 707.4 (West 2014) ("A person commits voluntary manslaughter when that person causes the death of another person, under circumstances which would otherwise be murder, if the person causing the death acts solely as the result of sudden, violent, and irresistible passion resulting from serious provocation sufficient to excite such passion in a person and there is not an interval between the provocation and the killing in which a person of ordinary reason and temperament would regain control and suppress the impulse to kill."); KAN. STAT. ANN. §21-5404(a)(1) (West 2014) ("Voluntary manslaughter is knowingly killing a human being committed: (1) Upon a sudden quarrel or in the heat of passion ...."); OHIO REV. CODE ANN. § 2903.03(A) (West 2006). The voluntary manslaughter statute reads, "No person, while under the influence of sudden passion or in a sudden fit of rage, either of which is brought on by serious provocation occasioned by the victim that is reasonably sufficient to incite the person into using deadly force, shall knowingly cause the death of another or the unlawful termination of another's pregnancy." OHIO REV. CODE ANN. $\S 2903.03(\mathrm{~A})$. Several states appear to allow provocation to be a complete defense if it qualifies as "excusable homicide." See, e.g., CAL. PENAL CODE $\$ 195$ (West 2014); FLA. STAT. ANN. $\$ 782.03$ (West 2007); People v. Hampton, 273 P. 854, 855-56 (Cal. Ct. App. 1929); Radillo v. State, 582 So. 2d 634, 636 (Fla. Dist. Ct. App. 1991).

19. See, e.g., HAW. REV. STAT. $§ 707-702(2)$ (West 2014) ("In a prosecution for murder or attempted murder in the first and second degrees it is an affirmative defense, which reduces the offense to manslaughter or attempted manslaughter, that the defendant was, at the time the defendant caused the death of the other person, under the influence of extreme mental or emotional disturbance for which there is a reasonable explanation. The reasonableness of the explanation shall be determined from the viewpoint of a reasonable person in the circumstances as the defendant believed them to be."); N.H. REV. STAT. ANN. § 630:2(1)(a) (2014) ("A person is guilty of manslaughter when he causes the death of another: (a) Under the influence of extreme mental or emotional disturbance caused by extreme provocation but which would otherwise constitute murder. ...").

20. See, e.g, ARK. CODE ANN. § 5-10-104(a)(1)(A) (West \& Supp. 2013) ("A person commits manslaughter if: (1)(A) The person causes the death of another person under circumstances that would be murder, except that he or she causes the death under the influence of extreme emotional disturbance for which 
Table 3. Provocation/EMED Formulations

\begin{tabular}{|c|c|c|}
\hline Formulation & Added Breadih Over More Narrow & States \\
\hline ENED (4) & Mental disturbance & $\mathrm{HI}, \mathrm{MT}, \mathrm{NV}, \mathrm{NH}, \mathrm{MPC}$ \\
\hline $\begin{array}{l}\text { EED (3) (Extreme } \\
\text { Enotional Distress) }\end{array}$ & $\begin{array}{l}\text { Any emotional disturbance; use of } \\
\text { force against anyone not just } \\
\text { provoker (even if cooling time) }\end{array}$ & $\begin{array}{c}\text { AR, CT, DE, KY, NY, } \\
\text { ND, OR, UT }\end{array}$ \\
\hline $\begin{array}{l}\text { Common Law } \\
\text { Provocalon } \\
\text { Mitigation (2) }\end{array}$ & (1) & $\begin{array}{c}\text { AL, AK, AZ, CA, CO, } \\
\text { DC, Federal, FL, GA, ID, } \\
\text { IL, IN, IA, KS, LA, ME, } \\
\text { MD, MA, MI, MN, MS, } \\
\text { MO, NE, NJ, NM, NC, } \\
\text { OH, OK, PA, RI, SC, } \\
\text { SD, TN, TX, VT, VA, } \\
\text { WA, WV, WI, WY }\end{array}$ \\
\hline [No Mitigation (1)] & - & - \\
\hline
\end{tabular}

\section{B. Discussion}

Two striking conclusions come from these displays. First, there is enormous variation in the formulation of the three doctrines across the fifty-two jurisdictions. It is not the case that a majority rule exists with outliers. Instead, we see large groups of states taking significantly different approaches than other large groups. And this is true even though, as noted above, each of the three or four categorizations used in a table group together formulations, among which, there is some variation. That is, the tables understate the degree of variation, yet still show enormous diversity.

Also look at Table 7 below. The states that take the same approach to the three doctrines are marked in the right-hand column with the same letter. ${ }^{21}$ That column shows that there are at least eighteen different patterns of formulation (A through $\mathrm{R}$ ) of these three doctrines into the general groupings. ${ }^{22}$

A second conclusion - that at least this writer finds striking-is the level of stinginess of most states in the excuses and mitigations they offer. Recall that during the 1960s and 1970s, three-quarters of the states codified or recodified their criminal law based in some significant part on the Model Penal Code, which was promulgated by the American Law Institute in $1962 .{ }^{23}$ Yet,

there is reasonable excuse."); N.Y. PENAL LAW $\S 125.20(2)$ (McKinney 2009) ("A person is guilty of manslaughter in the first degree when ... With intent to cause the death of another person, he causes the death of such person or of a third person under circumstances which do not constitute murder because he acts under the influence of extreme emotional disturbance, as defined in paragraph (a) of subdivision one of section 125.25. The fact that homicide was committed under the influence of extreme emotional disturbance constitutes a mitigating circumstance reducing murder to manslaughter in the first degree and need not be proved in any prosecution initiated under this subdivision.").

21. See infra Table 7.

22. See infra Table 7. There are $4 \times 4 \times 3$ possible combinations of approaches to the three doctrines, which equals forty-eight possibilities, so things theoretically could have been even more scattered.

23. See, e.g., Herbert Wechsler, Codification of Criminal Law in the United States: The Model Penal Code, 68 Colum. L. REV. 1425, 1427-28 (1968). 
this highly influential Model Code apparently had limited effect in gaining adherence to its formulations of these three doctrines, which were noticeably broader than earlier formulations. ${ }^{24}$ As the tables show, the Model Code's broader formulations represent a minority in every instance. ${ }^{25}$ Only one jurisdiction of the fifty-two, Hawaii, adopts the Model Penal Code's formulations on all three doctrines. ${ }^{26}$

Even states that follow the Model Penal Code on many other issues, including the formulation of homicide offenses, commonly reject its approach to these mitigations and excuses. ${ }^{27}$ And it is not just a matter of the Model Penal Code's persuasiveness with the state codification commissions. Even some states that initially followed the Model Penal Code on a doctrine later abandoned it in favor of a more narrow formulation. ${ }^{28} \mathrm{I}$ take this to be an illustration of the unfortunate distortion effect of American crime politics, which makes all mitigation and excuse defenses attractive targets, even if they may be essential to avoiding injustice and are perceived as essential by the shared intuitions of the state's voters. ${ }^{29}$

\section{THE INTERRELATION AMONG THE DOCTRINES}

These three doctrines obviously deal with related conditions of mental or emotional dysfunction or disturbance, and it would not be a surprise if they

24. See infra Table 7.

25. See infra Table 7.

26. See generally infra Table 7 (listing New Hampshire as an "H" pattern, even though its insanity defense is different from the Model Penal Code's formulation, because it may well be a bit broader in practice).

27. For example, both Pennsylvania and Texas reject the Model Penal Code formulations for insanity, MINOE, and provocation/EMED, but follow the Model Penal Code homicide formulation. See 18 PA. STAT. ANN. $\$ 2501$ (West 2014); TEX. PENAL CODE ANN. $\$ 19.01$ (West 2011); infra Table 7 (showing Pennsylvania's pattem (I2, M2, P2) and Texas's pattern (I2, M1, P2)).

28. MODEL PENAL CODE $\S 4.01$ n.31 (1962) (showing, for example, that Alabama, Missouri, Texas, and Utah all had "provisions substantially modeled on Section 4.01" in 1985). But each state subsequently narrowed their insanity formulation by dropping its control prong. ALA. CODE $\S 13 \mathrm{~A}-3-1$ (a) (1988); MO. ANN. STat. $\$ 562.086$ (West 2014); Tex. Penal Code. ANN. $\$$ 8.01(a) (West 2011); Utah Code ANN. $\$ 76-2-305$ (West 2014). Regarding provocation, for example, both Maine and New Jersey punished homicide that would be murder if not for "extreme emotional disturbance" as manslaughter. MODEL PENAL CODE $\S 210.3$ n.24 (1962). But both states now use language invoking the common-law provocation defense, allowing the defense when a crime that would otherwise be murder is committed "in the heat of passion resulting from a reasonable provocation" or "under the influence of extreme anger or extreme fear brought about by adequate provocation." ME. REV. STAT. tit. 17-A, § 203 (2014); N.J. STAT. ANN. § 2C:1 1-4 (West 2014).

29. See Paul H. Robinson et al., The Disutility of Injustice, 85 N.Y.U. L. REv. 1940, 1975-94 (2010) (discussing how the democratic process can produce liability rules that society sees as seriously unjust); Paul H. Robinson et al., The Modern Irrationalities of American Criminal Codes: An Empirical Study of Offense Grading, 100 J. CRIM. L. \& CRIMINOLOGY 709-64 (2010); Paul H. Robinson et al., Report on Offense Grading in New Jersey (University of Pennsylvania Law School 2011), available at http://papers.ssm.com/ sol3/papers.cfm?abstract_id=1737825; Paul H. Robinson, Report on Offense Grading in Pennsylvania (University of Pennsylvania Law School 2010), available at http://papers.ssm.com/sol3/papers.cfm? abstract_id=1527149. 
overlapped in some way. Because there is so much diversity in approach, it would seem that all manner of overlaps, or gaps, are possible. As the tables above show, there are at least four general approaches to formulating the insanity defense, three approaches to formulating the MINOE doctrine, and three approaches to formulating provocation/EMED. ${ }^{30}$ And, as the tables below make clear, these formulations occur in a host of combinations--eleven different combinations of insanity by MINOE, nine different combinations of insanity by EMED, and seven different combinations of MINOE by EMED. ${ }^{31}$ As noted above, there are eighteen different three-way combinations. $^{32}$

Are there discernable patterns to the combinations of approaches that a jurisdiction takes on these three issues? If so, is there some logic to the patterns? Legislatures, courts, and scholars sometimes make claims or assumptions about how the doctrines interact with one another. For example, it is sometimes argued that a particular formulation of one doctrine is appropriate because of the existence or breadth of another doctrine. Thus, it has been argued that we can abolish the insanity defense because MINOE is available to provide a defense for mental illness, ${ }^{33}$ and conversely, that MINOE is an insufficient substitute for an insanity defense ${ }^{34}$ and that we do not need and should not have a control prong in an insanity defense because the provocation defense already takes such matters into account. ${ }^{35}$ In other instances, a court or a legislature may define the scope of one doctrine by excluding from it situations covered by another. ${ }^{36}$ For example, the insanity defense has been defined to exclude the conditions traditionally associated with provocation. ${ }^{37}$ In still other instances, scholars have analyzed whether there are constitutional limits to adopting a position on one doctrine according to the position the jurisdiction takes on another. ${ }^{38}$

Are there, then, discernible patterns to the position a jurisdiction takes on the three doctrines, and is there a logic in the patterns? These are particularly interesting questions to criminal law scholars who would like their logical

30. See supra Tables 1-3.

31. See infra Tables 4-6.

32. See infra Table 7.

33. See, e.g., Raymond L. Spring, The End of Insanity, 19 WASHBURN L.J. 23, 32 (1979).

34. See, e.g., Marc Rosen, Insanity Denied: Abolition of the Insanity Defense in Kansas, 8 KAN. J.L. \& PUB. POL'Y 253, 260-61 (1999).

35. See, e.g., Stephen J. Morse, Retaining a Modified Insanity Defense, 477 ANNALS AM. ACAD. POL. \& SOC. SCI. (ThE INSANITY DEFENSE) 137, 142-43 (1985) ("The criminal law already allows excuses or mitigation for control problems-for example, duress and the provocation/passion formula to reduce murder to manslaughter.").

36. See infra notes $37-38$ and accompanying text.

37. See, e.g., Thompson v. Commonwealth, 70 S.E.2d 284, 292 (Va. 1952) ("Frenzy arising solely from the passion of anger and jealousy, regardless of how furious, is not insanity." (internal quotation marks omitted)).

38. See, e.g., Tyler Ellis, Mental Illness, Legal Culpability, \& the Fourteenth Amendment: Why Due Process Allows States to Choose a Mens Rea Insanity Defense over a M'Naghten Approach (2014), available at http://papers.ssm.com/sol3/papers.cfm?abstract_id=2390294. 
arguments and analyses to have real world effects. Consider each of the three doctrines in pair with one another, then we will look at the variety of three-way combinations. $^{39}$

\section{A. Insanity and MINOE}

Consider the interrelation of the insanity and MINOE formulations in Table 4.

Table 4. Insanity x MINOE

\begin{tabular}{|c|c|c|c|}
\hline $\begin{array}{l}\text { MINOE: } \\
\text { Insanity: }\end{array}$ & $\begin{array}{l}1 \text { Camnot Negate } \\
\text { Any Element }\end{array}$ & $\begin{array}{c}2 \text { Negate Only } \\
\text { Intent }\end{array}$ & 3 Negate Any Element \\
\hline $\begin{array}{l}\text { Cognitive \& } \\
\text { Control (4) }\end{array}$ & $\mathrm{DC}, \mathrm{MI}, \mathrm{VA}$ & $\begin{array}{l}\mathrm{KY}, \mathrm{MA}, \mathrm{NM} \\
\text { RI, WY }\end{array}$ & $\begin{array}{c}\mathrm{AR}, \mathrm{CT}, \mathrm{HI}, \mathrm{MD}, \mathrm{NH}, \\
\mathrm{OR}, \mathrm{VT}, \mathrm{WV}, \mathrm{MPC}\end{array}$ \\
\hline $\begin{array}{l}\text { All-cognitive Onily } \\
\text { (3) (mapairment } \\
\text { sufficient) }\end{array}$ & $\mathrm{AL}, \mathrm{DE}, \mathrm{IL}$ & $N Y$ & $\begin{array}{c}\text { AK, Federal, IN, ME, } \\
\text { TN }\end{array}$ \\
\hline $\begin{array}{l}\text { M'Naghten (2) } \\
\text { (cognitive only, } \\
\text { absolute required) }\end{array}$ & $\begin{array}{c}\text { AZ, FL, GA, } \\
\text { LA, MN, MS, } \\
\text { OK, SC, TX, WI }\end{array}$ & $\begin{array}{c}\text { CA, IA, NE, NC, } \\
\text { PA, SD }\end{array}$ & $\mathrm{CO}, \mathrm{MO}, \mathrm{NJ}, \mathrm{OH}, \mathrm{WA}$ \\
\hline Abolition (1) & - & ND & $\mathrm{ID}, \mathrm{KS}, \mathrm{MT}, \mathrm{NV}, \mathrm{UT}$ \\
\hline
\end{tabular}

Some cells seem to have some logic to them. The cell in the upper-right-hand corner contains states that give the broadest insanity formulation as well as the broadest MINOE formulation, following the Model Penal Code's lead in both respects. They seem to show a consistent approach: wanting a full and broad assessment of an offender's blameworthiness.

The states in the lower-right-hand corner have abolished the insanity defense, so one would think that they hardly have a choice other than to provide a fairly robust MINOE doctrine. But note the resistance of North Dakota to this reasoning: it abolishes insanity but also limits MINOE. ${ }^{40}$ Similarly, the states in the upper-left-hand corner, having barred any MINOE, may have felt compelled to give a fairly broad insanity defense.

But then come the many states in the lowest-populated left-hand comer, which not only bar any MINOE, but also allow the most narrow formulation of an insanity defense: the bare M'Naghten rule. Clearly they are suspicious of, if not hostile to the idea of mental illness mitigating or excusing liability. There is rich literature on such suspicions, but it would seem difficult for a state to claim to be committed to the principle of justice when it acts upon such suspicions in this way. ${ }^{41}$

39. See infra Tables 4-7.

40. See N.D. CENT. CODE ANN. \$ 12.1-04.1-01 (West 2013).

41. See, e.g., Michael L. Perlin, "The Borderline Which Separated You From Me": The Insanity Defense, the Authoritarian Spirit, the Fear of Faking, and the Culture of Punishment, 82 IOWA L. REV. 1375, 
So there might seem to be some logic to the placement of jurisdictions in one cell or another, but those lines of argument are contradictory with one another. Do the states sharing a cell really reflect this shared point of view, or is the pattern one sees in the table just a product of essentially disconnected formulation decisions producing a somewhat random distribution in which, by chance, most cells get filled?

\section{B. Insanity and Provocation/EMED (Extreme Mental or Emotional Disturbance)}

Consider the interrelation of the insanity and provocation formulations in Table 5.

Table 5. Insanity x Provocation/EMED

\begin{tabular}{|c|c|c|c|}
\hline $\begin{array}{l}\text { Provocation/EMED } \\
\text { Insanity }\end{array}$ & $\begin{array}{l}2 \text { Common Law } \\
\text { Provocation } \\
\text { Mitigation }\end{array}$ & $\begin{array}{l}3 \text { Extreme } \\
\text { Emotional } \\
\text { Disturbance }\end{array}$ & $\begin{array}{l}4 \text { Extreme } \\
\text { Mental or } \\
\text { Emotional } \\
\text { Disturbance }\end{array}$ \\
\hline Cognitive \& Control(4) & $\begin{array}{c}\text { DC, MD, MA, MI, } \\
\text { NM, RI, VT, VA, } \\
\text { WV, WY }\end{array}$ & $\mathrm{AR}, \mathrm{CT}, \mathrm{KY}, \mathrm{OR}$ & $\mathrm{HI}, \mathrm{NH}, \mathrm{MPC}$ \\
\hline $\begin{array}{l}\text { ALI-Cognitive Only (3) } \\
\text { (mpairnent sufficient) }\end{array}$ & $\begin{array}{l}\text { AL, AK, Federal, } \\
\text { IL, IN, ME, TN }\end{array}$ & DE, NY & - \\
\hline $\begin{array}{l}\text { MNaghten (2) } \\
\text { (cognitive only, } \\
\text { absolute required) }\end{array}$ & $\begin{array}{l}\text { AZ, CA, CO, FL, } \\
\text { GA, IA, LA, MN, } \\
\text { MS, MO, NE, SC, } \\
\text { SD, NJ, NC, OH, } \\
\text { OK, PA, TX, WA }\end{array}$ & - & - \\
\hline Abolition (1) & $\mathrm{ID}, \mathrm{KS}$ & $\mathrm{ND}, \mathrm{UT}$ & MT, NV \\
\hline
\end{tabular}

EMED and EED are so generally rejected that there is not much interactive effect to speculate about, but there are a few interesting points. Every state that follows the common law's M'Naghten rule for insanity also rejects any broadening of provocation from its common-law form. This trend is perhaps no surprise. ${ }^{42}$ Most of these states never had a modern recodification based upon the Model Penal Code. ${ }^{43}$ Showing the same logic, the states that go the farthest in following the Model Penal Code's broadening of insanity (to include a control prong) are also the states most likely to adopt the Model Penal Code's EMED or EED broadening of provocation.

1377, 1390-91 (1997); William French Smith, Limiting the Insanity Defense: A Rational Approach to Irrational Crimes, 47 MO. L. REV. 605, 606-11 (1982).

42. See, e.g., Paul H. Robinson \& Michael T. Cahill, Can a Model Penal Code Secand Save the States from Themselves?, 1 OHIO Sr. J. CRIM. L. 169, 169-70 (2003). See generally Sanford H. Kadish, Fifty Years of Criminal Law: An Opinionated Review, 87 CALIF. L. REv. 943, 948-50 (1999) (recognizing that not all of the reforms after the Proposed Final Draft of the Model Penal Code were equally reformative).

43. See supra note 42 and accompanying text. 
In searching for a silver lining, one might observe that the chart shows a certain consistency in approach. It suggests that a state's formulations are not the product of a completely random process without rhyme or reason. On the other hand, one might wonder about the dynamics of the lower-right-hand cells North Dakota, Utah, Montana, and Nevada. These states have abolished the insanity defense, yet followed the Model Penal Code's broadening of common-law provocation. ${ }^{44}$ It is not obvious that there is a logical reason that would tie these two positions together. Perhaps we are back to randomness in effect. Or perhaps there is a structural-process effect at work here rather than the effect of a reasoned explanation. ${ }^{45}$ One might speculate that the "small-state" effect is at work in these four states, leading them to follow the Model Penal Code's broader EMED or EED, but because insanity is a high-profile defense, it is one of the few issues that would attract attention and provoke political debate, leading to its abolition. ${ }^{46}$ Note too that the four states are geographically close, which creates the possibility that debates in one state may spill over to have an effect next door.

\section{MINOE and Provocation/EMED (Extreme Mental or Emotional Disturbance)}

Consider the interrelation of the provocation and MINOE doctrines in Table 6 .

Table 6. Provocation/EMED x MINOE

\begin{tabular}{|l|c|c|c|}
\hline MINOE: & $\begin{array}{c}\text { Cannot Negate } \\
\text { Any Element }\end{array}$ & $\begin{array}{c}\text { Negate Only } \\
\text { Intent }\end{array}$ & $\begin{array}{c}3 \text { Negate Any } \\
\text { Element }\end{array}$ \\
\hline $\begin{array}{l}\text { Extreme Mental or } \\
\text { Emotional Disturbance (4) }\end{array}$ & - & - & $\begin{array}{c}\text { HI, MT, NV, NH, } \\
\text { MPC }\end{array}$ \\
\hline $\begin{array}{l}\text { Extreme Emotional } \\
\text { Disturbance (3) }\end{array}$ & DE & KY, NY, ND & AR, CT, OR, UT \\
\hline $\begin{array}{c}\text { Common Law Provocation } \\
\text { Mitigation (2) }\end{array}$ & $\begin{array}{c}\text { AL, AZ, DC, } \\
\text { FL, GA, IL, LA, } \\
\text { MI, MN, MS, } \\
\text { OK, SC, TX, } \\
\text { VA, WI }\end{array}$ & $\begin{array}{c}\text { CA, IA, MA, } \\
\text { NE, NC, NM, RI, SD, WY }\end{array}$ & $\begin{array}{c}\text { AK, CO, Federal, } \\
\text { ID, NN, KS, ME, } \\
\text { MD, MO, NJ, OH, } \\
\text { TN, VT, WA, WV }\end{array}$ \\
\hline
\end{tabular}

The lower-left-hand cell contains jurisdictions that reject both the Model Penal Code's attempt to broaden common-law provocation and its attempt to allow the introduction of mental illness evidence that would negate a required offense element. Most of these states never codified or recodified their criminal

44. See supra Table 5.

45. See generally infra Part III (discussing the "small-state" effect).

46. See infra Part III. 
law during the wave of the $1960 \mathrm{~s}$ and $1970 \mathrm{~s}^{47}$ The lower-right-hand cell kept common-law provocation, as most states did, yet adopted full MINOE per the Model Penal Code-an interesting combination of views.

The two upper-right-hand cells are even more interesting, but for a different reason. They follow the Model Penal Code in providing both full MINOE and broad EMED or at least EED. It is perhaps no surprise, then, that five of the eight states also adopt the broader insanity formulation, recognizing a control prong as the Model Penal Code does. But the other three-Montana, Nevada, and Utah—abolish the insanity defense altogether! There is no middle ground.

What is going on here? Why only the extremes? One could speculate, with no real evidence, that this is an example of the small-state effect, where these eight states all dutifully followed the Model Penal Code, but in three of the states, the insanity defense caught the spotlight and ended up getting the full public-panic treatment. ${ }^{48}$ Why in those three states and not the other five? Perhaps we see here a certain randomness in the criminal lawmaking process, including the effect of timing, local news coverage, local politics, and other such special factors unrelated to logical analysis.

\section{States Sharing the Same Approach to All Three Doctrines}

The variety of combinations that one sees in the two-way tables above, as one might guess, is even more exaggerated when one looks at the variety of three-way combinations. Table 7 shows the eighteen different patterns.

47. Robinson \& Cahill, supra note 42.

48. See supra Table 1. 
Table 7. Summary of Three-Way Combinations

\begin{tabular}{|c|c|c|c|c|}
\hline JURISDICTION & NSSANIIY & MNOE & Prov/EMED & Pattern \\
\hline Alabama & I3 - ALI cognitive & M1-none & P2-CL prov & A \\
\hline Ulinais & I3 - ALI cognitive & M1-none & P2-CL prov & A \\
\hline Alaska & I3 - ALI cognitive & M3-any & $\mathrm{P} 2-\mathrm{CL}$ prov & $\mathrm{B}$ \\
\hline Federal & I3 - ALI cognitive & M3 - any & P2-CL prov & $\mathrm{B}$ \\
\hline Indiana & I3 - ALI cognitive & M3 - any & P2 - CL prov & B \\
\hline Maine & I3 - ALI cognitive & M3 - any & P2 - CL prov & $\mathrm{B}$ \\
\hline Tennessee & I3 - ALI cognitive & M3-any & $\overline{\mathrm{P} 2}-\mathrm{CL}$ prov & $\mathrm{B}$ \\
\hline Arizona & I2 - M'Naghten & M1-none & P2-CL prov & $\mathrm{C}$ \\
\hline Florida & I2 - M'Naghten & M1-none & $\mathrm{P} 2-\mathrm{CL}$ prov & $\mathrm{C}$ \\
\hline Georgia & I2-M'Naghten & Ml-none & $\mathrm{P} 2-\mathrm{CL}$ prov & $\mathrm{C}$ \\
\hline Louisiana & I2-M'Naghten & M1-none & $\mathrm{P} 2-\mathrm{CL}$ prov & $\mathrm{C}$ \\
\hline Minnesota & I2-M'Naghten & M1-none & $\mathrm{P} 2-\mathrm{CL}$ prov & $\mathrm{C}$ \\
\hline Mississippi & I2-M'Naghten & M1-none & P2-CL prov & $\mathrm{C}$ \\
\hline Oklaboma & I2 - M'Naghten & M1-none & $\mathrm{P} 2-\mathrm{CL}$ prov & $\mathrm{C}$ \\
\hline South Carolina & I2 - M'Naghten & M1-none & P2 - CL prov & $\mathrm{C}$ \\
\hline Texas & 12-M'Naghten & M1-none & P2 - CL prov & $\mathrm{C}$ \\
\hline Wisconsin & I2-M'Naghten & M1-none & $\mathrm{P} 2-\mathrm{CL}$ prov & $\mathrm{C}$ \\
\hline Arkansas & I4 - control & $\mathrm{M} 3$ - any & P3 - EED & $\mathrm{D}$ \\
\hline Connecticut & I4-control & M3 - any & P3-EED & $\mathrm{D}$ \\
\hline Oregon & I4 - control & M3 - any & P3 - EED & $\mathrm{D}$ \\
\hline Colorado & I2-M'Naghten & M3 - any & $\mathrm{P} 2-\mathrm{CL}$ prov & $\mathrm{E}$ \\
\hline Missoun & 12 -M'Naghten & M3 - any & $\mathrm{P} 2-\mathrm{CL}$ prov & $\mathrm{E}$ \\
\hline New lersey & I2 - M'Naghten & M3 - any & P2-CL prov & $\mathrm{E}$ \\
\hline Ohio & I2-M'Naghten & M3 - any & P2 - CL prov & E \\
\hline Washington & I2-M'Naghten & M3 - any & $\mathrm{P} 2-\mathrm{CL}$ prov & $E$ \\
\hline D.C. & I4 - control & M1-none & P2-CL prov & $\mathrm{F}$ \\
\hline Michigan & I4-control & M1--none & $\mathrm{P} 2-\mathrm{CL}$ prov & $\mathrm{F}$ \\
\hline Virginia & I4-control & M1-none & P2-CL prov & $\mathrm{F}$ \\
\hline Delaware & I3 - ALI cognitive & M1-none & $\mathrm{P3}-\mathrm{EED}$ & $\mathrm{G}$ \\
\hline Hawail & I4 - control & M3 - any & P4-EMED & $\mathrm{H}$ \\
\hline $\mathrm{MPC}$ & I4 - control & M3 - any & P4-EMED & $\mathrm{H}$ \\
\hline New Hampshire & I4 - control & M3 - any & P4 - EMED & $\mathrm{H}$ \\
\hline Idaho & I1 - abolition & M3 - any & P2-CL prov & I \\
\hline Kansas & I1 - abolition & M3 - any & $\mathrm{P} 2-\mathrm{CL}$ prov & I \\
\hline California & I2 - M'Naghten & M2 - only intent & P2 - CL prov & $\mathrm{J}$ \\
\hline lowa & I2 - M'Naghten & M2 - only intent & $\mathrm{P} 2-\mathrm{CL}$ prov & $\mathrm{J}$ \\
\hline Nebraska & I2-M'Naghten & $\mathrm{M} 2$ - only intent & P2 - CL prov & $\mathrm{J}$ \\
\hline North Carolina & I2 - M'Naghten & M2 -- only intent & P2-CL prov & $\mathbf{J}$ \\
\hline Pennsylvania & $\sqrt{2-M^{\prime} N a g h t e n}$ & M2 - only intent & P2-CL prov & $\mathrm{J}$ \\
\hline South Dakota & I2-M'Naghten & M2 - only intent & P2-CL prov & $\mathbf{J}$ \\
\hline Kentucky & I4 - control & M2 - only intent & P3-EED & $\bar{K}$ \\
\hline Maryland & I4 - control & M3 - any & P2 - CL prov & $\mathrm{L}$ \\
\hline Vermont & I4- control & M3 - any & P2-CL prov & $\mathrm{L}$ \\
\hline West Virginia & I4- control & M3 - any & P2 - CL prov & $\mathrm{L}$ \\
\hline Massachusetts & I4 - control & M2 - only intent & P2 -- CL prov & $\overrightarrow{\mathrm{M}}$ \\
\hline Rhode Island & I4 - control & M2 - only intent & P2-CL prov & $\mathrm{M}$ \\
\hline Wyoming & I4 - control & M2 - only intent & P2-CL prov & $\mathrm{M}$ \\
\hline
\end{tabular}




\begin{tabular}{|c|c|c|c|c|}
\hline UURISDICTION & INSANITY & MTNOE & Prov/EMED & Pattern \\
\hline Montana & I1 - abolition & $\mathrm{M} 3-$ any & P4-EMED & $\mathrm{N}$ \\
\hline Nevada & I1-abolition & M3 - any & P4 - EMED & $\mathrm{N}$ \\
\hline New Mexico & I4-control & $\begin{array}{l}\text { M2 - only } \\
\text { premed }\end{array}$ & P2 - CL prov & $\mathrm{O}$ \\
\hline New York & I3 - ALI cognitive & $\mathrm{M} 2-$ only intent & P3 - EED & $\mathrm{P}$ \\
\hline North Dakota: & Il - abolition & M2 - only intent & P3-EED & $Q$ \\
\hline Utah & I1 - abolition & M3 - any & P3-EED & $\mathrm{R}$ \\
\hline
\end{tabular}

Key to Table 7:

From Table 1 (Insanity):

I4 - control $=$ cognitive and control prongs

I3 - ALI cognitive = cognitive only "does not appreciate" or "lacks substantial appreciation," etc.

I2 -- M'Naghten = cognitive only "does not know"

I $1-$ abolition $=$ no insanity defense

From Table 2 (MINOE):

M3 - any = negates whatever culpability is applicable

M2 - only intent $=$ negates only intention (e.g., murder)

$\mathrm{M} 1-$ none $=$ mental illness cannot negate an offense element

From Table 3 (Provocation/EMED):

P4 - EMED = MPC broader form including mental disturbance

$\mathrm{P} 3-\mathrm{EED}=\mathrm{MPC}$ version

$\mathrm{P} 2-\mathrm{CL}$ prov $=$ "heat of passion," etc.

In Table 7, the states that share the same approach to all three doctrines share the same letter in the far right column. The level of diversity is striking. Eighteen different combinations of approaches exist (A through $\mathrm{R}$ ). The most common pattern is $\mathrm{C}$, with ten states following it. After that, the largest group consists of six states sharing a pattern $(\mathrm{J})$, five states sharing two patterns ( $B$ and $E$ ), and five groups of three states sharing different patterns (D, F, H, L, and M). Finally, three pairs of states share a pattern (A, I, and N), and another six states have a unique combination (Delaware, Kentucky, New Mexico, New York, North Dakota, and Utah).

The single largest group, pattern $\mathrm{C}$, consists of states that tend to follow the common-law rule, unaffected by the Model-Penal-Code-based recodifications. They adopt the most narrow formulation of each of the three doctrines.

Beyond that, the states are seriously splintered in their approaches. One might conclude that the Model Penal Code did have an effect, not so much in gaining adherents to its formulations, but at least in pushing most states from their strict reliance upon the common-law approach-usually to some place short of the Model Penal Code position. 


\section{CONCLUSION}

What conclusions can one draw from this analysis of the state approaches to these three doctrines: insanity, MINOE, and provocation/EMED? Several points have already been hinted at.

First, there is an astounding level of diversity among the American jurisdictions regarding the approaches to each doctrine (Tables 1 through 3 ) and among the different combinations of approaches taken to the three doctrines (Tables 4 through 6)-most of the cells in the latter tables are populated. ${ }^{49}$ And from Table 7 we see that, on average, a state shares its pattern of formulation of these doctrines with only 3.7 other jurisdictions of the fifty-two. ${ }^{50}$

The common-law view might seem a strong, unifying view, at least among a minority group, but this conclusion is a bit of an illusion. ${ }^{51}$ While these jurisdictions are close enough to one another in their formulations to be grouped together in our tables (because they are dependent upon judicial formulation and development) they in fact have many differences among them, albeit of less dramatic effect than their differences with the Model-Penal-Codeinfluenced jurisdictions.

A second conclusion is that the analysis destroys any pleasant illusion some scholars might have had about the controlling effect of the Model Penal Code on these doctrines. The Model Penal Code has had an enormous effect in some areas, but these mitigations and excuses are an area in which it gained few converts. The Model Penal Code represents the minority view on each of the doctrines: only twenty-three of the fifty-two jurisdictions follow it on MINOE, only sixteen on insanity, and only twelve on EMED or EED. ${ }^{52}$

A third conclusion follows from the perspective the survey gives on the influences on criminal law legislation. Consider, for example, what was referred to previously as the small-state effect. ${ }^{53}$ It would seem that the Model Penal Code had a greater effect with these doctrines on the smaller states (by population). Note that such states are quite overrepresented in the upper-right-hand cells of Tables 1 through 6 (which always contain the broad Model Penal Code view). ${ }^{54}$ This makes sense when one considers the common dynamics of the recodification process in the states. Smaller states presumably have smaller legislative staffs and reform budgets and may have less legislative activity generally. If they are able to successfully process legislation as gargantuan as a new criminal code, they may only be able to do so by largely

49. See supra Tables $1-6$.

50. $10 \times 9$ (10 states share with 9 others $)+6 \times 5+10 \times 4+14 \times 2+6 \times 1+6 \times 0=194 / 52=3.7$. See supra Table 7

51. See supra Tables 1-3.

52. See supra Tables $1-3$.

53. See supra Part II.

54. See supra Tables 1-6. 
following the model, with their legislative changes to the model limited to particularly prominent issues that happen to catch their attention.

Note that some small states were never able to enact a new code. ${ }^{55}$ Thus, the small-state distribution is a bit bimodal: either they enacted a code heavily influenced by the Model Penal Code or they failed to enact a modern recodification.

The large, populous states as a group show a different dynamic. Lots of legislative activity and lobbyist interest in debating, or blocking codification formulations they do not support, produced codes that were much more likely to alter the model. The big-state fights also produced their own share of failures to enact a modern criminal code, even after an enormous investment of time and effort. The repeated failures to recodify federal criminal law is the most dramatic example, but failures occurred in the states as well, as with California, Massachusetts, and Michigan. ${ }^{56}$ Notice that many of the states that regularly appear in the cells taking the most narrow approach are populous, such as California (1st in population among the fifty states, including the District of Columbia), Louisiana (25th), Oklahoma (28th), South Carolina (24th), and Wisconsin (20th). None of these five states successfully recodified their criminal laws during the wave sparked by the Model Penal Code. ${ }^{57}$

Are most jurisdictions, in reaching their formulation decisions, making carefully reasoned analyses that take into account what they have done in other related doctrines? Scholars attempting to divine the underlying reason for a state's pattern of formulations may have to face the disappointing reality that there is often no underlying logic. How else can one explain the dizzying array of different combinations?

It may be that the formulation is as much a product of chance as logic. Did a headline case spark public unhappiness on an issue, as with the Hinckley insanity acquittal? What kind of debates are neighboring jurisdictions having, and do the states share media sources? What other codifications were complete when the state undertook its recodification? What kind of political compromises were needed to reach agreement on a formulation? All of these factors are independent of the wisdom and rationality of the resulting formulation.

55. For example, Nevada, West Virginia, Idaho, Rhode Island, the District of Columbia, and Vermont have never enacted a modern codification of their criminal law, although many of them have at one point or another thought seriously about it. See supra Tables 1-7.

56. See JoInt Legis. Comm. For Revision PENal Code, PEnal Code Revision Draft, Tentattve Draft No. 1 (Cal. 1967); Mass. Crim. L. Revision Comm., Proposed Criminal Code of MASSACHUSETTS WITH COMMISSION NOTES (Mass. 1972); SPECIAL COMM. MICH. ST. B. FOR REVISION CRIM. CODE, MICHIGAN REVISED CRIMINAL CODE, FINAL DRAFT (Mich. 1967); NAT'L COMM'N ON REFORM OF FED. CRIM. LAWS, FINAL REPORT OF THE NATIONAL COMMISSION ON REFORM FEDERAL CRIMINAL LAWS: A PROPOSED NEW FEDERAL CRIMINAL CODE (1971), available at http://www.ndcourts.gov/court/ Resource/CriminalCode/FinalReport.pdf.

57. See Herbert Wechsler, Forward to MODEl PENAL CODE: OfFICIAL Draft AND EXPLANATORY NOTES, at xi (1985) (listing all jurisdictions that enacted criminal code reform after promulgation of the Model Penal Code, as well as a number of jurisdictions that tried and failed). 
Yes, one can discern some states that tend to be generally more sympathetic to these mitigations and excuses - see the upper-right-hand cells in Tables 4 through 6 - and some states that seem generally hostile to these mitigations and excuses--see the bottom-left-hand cells in Tables 4 through 6 - but, beyond that, there are many combinations for which there seems little rhyme or reason. 


\section{APPENDIX: CITATION TABLE}

\begin{tabular}{|c|c|c|c|}
\hline JURISDICTION & INSANITY & MINOE & Prov/EMED \\
\hline Alabama & $\begin{array}{l}\text { ALA. CODE } \\
\$ 13 A-3-1 \\
\end{array}$ & $\begin{array}{l}\text { ALA. CODE } \\
\S 13 \mathrm{~A}-3-1\end{array}$ & $\begin{array}{l}\text { ALA. CODE } \\
\S 13 \mathrm{~A}-6-3\end{array}$ \\
\hline Alaska & $\begin{array}{l}\text { ALASKA STAT. } \\
\$ 12.47 .010\end{array}$ & $\begin{array}{l}\text { ALASKA STAT. } \\
\S 12.47 .020\end{array}$ & $\begin{array}{l}\text { ALASKA STAT. } \\
\S 11.41 .115\end{array}$ \\
\hline Arizona & $\begin{array}{l}\text { ARIZ. REV. STAT. } \\
\text { ANN. } \$ 13-502\end{array}$ & $\begin{array}{l}\text { State v. Mott, 931 } \\
\text { P.2d } 1046 \text { (Ariz. } \\
\text { 1997) (en banc) }\end{array}$ & $\begin{array}{l}\text { ARIZ REV. STAT. } \\
\text { ANN. } § 13-1103\end{array}$ \\
\hline Arkansas & $\begin{array}{l}\text { ARK. CODE ANN. } \\
\$ 5-2-312\end{array}$ & $\begin{array}{l}\text { ARK. CODE ANN. } \\
\S 5-2-303\end{array}$ & $\begin{array}{l}\text { ARK. CODE ANN. } \\
\S 5-10-104 \text {. }\end{array}$ \\
\hline Calforna & $\begin{array}{l}\text { CAL. PENAL CODE } \\
\S \S 25,28\end{array}$ & $\begin{array}{l}\text { CAL. PENAL CODE } \\
\S 28 ; \text { People v. } \\
\text { Saille, } 820 \text { P.2d } \\
588 \text { (Cal. 1991) }\end{array}$ & $\begin{array}{l}\text { CAL. PENAL CODE } \\
\S 195\end{array}$ \\
\hline Colorado & $\begin{array}{l}\text { COLO. REV. STAT. } \\
\text { ANN. } \$ 16-8-101.5\end{array}$ & $\begin{array}{l}\text { COLO. REV. STAT. } \\
\text { ANN. } \$ 18-1-803\end{array}$ & $\begin{array}{l}\text { COLO. REV. STAT. } \\
\text { ANN. \& 18-3-103 }\end{array}$ \\
\hline Connecticut & $\begin{array}{l}\text { CONN. GEN. STAT. } \\
\text { ANN. } \$ 53 \mathrm{a}-13\end{array}$ & $\begin{array}{l}\text { State v. Burge, } \\
487 \text { A.2d } 532 \\
\text { (Conn. 1985) }\end{array}$ & $\begin{array}{l}\text { CONN. GEN. STAT. } \\
\text { ANN. } § 53 \mathrm{a}-54 \mathrm{a}\end{array}$ \\
\hline D.C. & $\begin{array}{l}\text { Howard v. United } \\
\text { States, } 954 \text { A.2d } \\
415 \text { (D.C. } 2008 \text { ) }\end{array}$ & $\begin{array}{l}\text { Bethea v. United } \\
\text { States, } 365 \text { A.2d } \\
64 \text { (D.C. 1976) }\end{array}$ & $\begin{array}{l}\text { Dean v. United } \\
\text { States, } 377 \text { A. } 2 d \\
423 \text { (D.C. 1977) }\end{array}$ \\
\hline Delaware & $\begin{array}{l}\text { DEL. CODE ANN. } \\
\text { tit. } 11, \S 401\end{array}$ & $\begin{array}{l}\text { Bates v. State, } 386 \\
\text { A.2d } 1139 \text { (Del. } \\
\text { 1978) }\end{array}$ & $\begin{array}{l}\text { DEL. CODE ANN. } \\
\text { tit. } 11, \S 641\end{array}$ \\
\hline Flonda & $\begin{array}{l}\text { FLA. STAT. ANN. } \\
\S 775.027\end{array}$ & $\begin{array}{l}\text { Chestnut v. State, } \\
538 \text { So. 2d } 820 \\
\text { (Fla. 1989) }\end{array}$ & $\begin{array}{l}\text { FLA. STAT. ANN. } \\
\S 782.03\end{array}$ \\
\hline Georgia & $\begin{array}{l}\text { GA. CODE ANN. } \\
\S 16-3-2\end{array}$ & $\begin{array}{l}\text { Hudson v. State, } \\
319 \text { S.E.2d } 28 \\
\text { (Ga. Ct. App. } \\
\text { 1984) }\end{array}$ & $\begin{array}{l}\text { GA. CODE ANN. } \\
\S 16-5-2\end{array}$ \\
\hline Irawail & $\begin{array}{l}\text { HAW. REV. STAT. } \\
\S 704-400\end{array}$ & $\begin{array}{l}\text { HAW. REV. STAT. } \\
\S 704-401\end{array}$ & $\begin{array}{l}\text { HAW. REV. STAT. } \\
\$ 707-702\end{array}$ \\
\hline Idaho & $\begin{array}{l}\text { IDAHO CODE ANN. } \\
\S \mathbf{1 8 - 2 0 7} \\
\end{array}$ & $\begin{array}{l}\text { IDAHO CODE ANN. } \\
\S 18-207\end{array}$ & $\begin{array}{l}\text { IDAHO CODE ANN. } \\
\$ 18-4012\end{array}$ \\
\hline Illinois & $\begin{array}{l}720 \text { ILL. COMP. STAT. } \\
5 / 6-2 \text { (found } \\
\text { unconstitutional) }\end{array}$ & $\begin{array}{l}\text { People v. Hulitt, } \\
838 \text { N.E. } 2 \text { d } 148 \\
\text { (IIl. App. Ct. } \\
\text { 2005) }\end{array}$ & $\begin{array}{l}720 \text { ILL. COMP. STAT. } \\
\text { 5/9-2 }\end{array}$ \\
\hline Indiana & $\begin{array}{l}\text { IND. CODE ANN. } \\
\S 35-41-3-6\end{array}$ & $\begin{array}{l}\text { Sanchez v. State, } \\
749 \text { N.E.2d } 509 \\
\text { (Ind. 2001) }\end{array}$ & $\begin{array}{l}\text { IND. CODE ANN. } \\
\S 35-42-1-3\end{array}$ \\
\hline lowa & $\begin{array}{l}\text { IOWA CODE ANN. } \\
\S 701.4\end{array}$ & $\begin{array}{l}\text { Anfinson v. State, } \\
758 \text { N.W.2d } 496 \\
\text { (Iowa 2008) }\end{array}$ & $\begin{array}{l}\text { IOWA CODE ANN. } \\
\S 707.4\end{array}$ \\
\hline Kansas & $\begin{array}{l}\text { KAN. STAT. ANN. } \\
\S 21-5209\end{array}$ & $\begin{array}{l}\text { KAN. STAT. ANN. } \\
\$ 21-5209\end{array}$ & $\begin{array}{l}\text { KAN. STAT. ANN, } \\
\S 21-5404\end{array}$ \\
\hline
\end{tabular}




\begin{tabular}{|c|c|c|c|}
\hline JURISDICTION & INSANITY & MINOE & Prov/EMED \\
\hline Kentucky & $\begin{array}{l}\text { KY. REV. STAT. ANN. } \\
\S 504.020\end{array}$ & $\begin{array}{l}\text { McGuire v. } \\
\text { Commonwealth, } \\
885 \text { S.W.2d } 931 \\
\text { (Ky. 1994) }\end{array}$ & $\begin{array}{l}\text { KY. REV. STAT. ANN. } \\
\S \S 507.020,507.030\end{array}$ \\
\hline Louisiana & $\begin{array}{l}\text { LA. REV. STAT. ANN. } \\
\S 14: 14\end{array}$ & $\begin{array}{l}\text { State v. Jones, } 359 \\
\text { So. } 2 \text { d } 95 \text { (La. } \\
\text { 1978) }\end{array}$ & $\begin{array}{l}\text { LA. REV. STAT. ANN. } \\
\S 14: 31(\text { A) }\end{array}$ \\
\hline Maine & $\begin{array}{l}\text { ME. REV. STAT. tit. } \\
17-A, \S 39\end{array}$ & $\begin{array}{l}\text { ME. REV. STAT. tit. } \\
17-A, \S 38\end{array}$ & $\begin{array}{l}\text { ME. REV. STAT. tit. } \\
17-A, \S 203\end{array}$ \\
\hline Maryland & $\begin{array}{l}\text { MD. CODE ANN., } \\
\text { CrIM. Proc. } \$ 3-109\end{array}$ & $\begin{array}{l}\text { Hoey v. State, } 536 \\
\text { A.2d } 622(\mathrm{Md} . \\
1988)\end{array}$ & $\begin{array}{l}\text { Girouard v. State, } \\
583 \text { A.2d } 718(\mathrm{Md} \text {. } \\
1991)\end{array}$ \\
\hline Massachusets & $\begin{array}{l}\text { Commonwealth v. } \\
\text { Brown, } 434 \text { N.E.2d } \\
973 \text { (Mass. 1982); } \\
\text { Commonwealth v. } \\
\text { McHoul, 226 N.E.2d } \\
556 \text { (Mass. 1967) } \\
\end{array}$ & $\begin{array}{l}\text { Commonwealth v. } \\
\text { Johnston, } 828 \\
\text { N.E.2d } 568 \text { (Mass. } \\
\text { App. Ct. 2005) }\end{array}$ & $\begin{array}{l}\text { Commonwealth v. } \\
\text { Carrion, } 552 \text { N.E.2d } \\
558 \text { (Mass. 1990) }\end{array}$ \\
\hline Michigan & $\begin{array}{l}\text { MiCH. COMP. LAWS } \\
\text { ANN. } § 768.21 \mathrm{a}\end{array}$ & $\begin{array}{l}\text { People v. Pahoski, } \\
2012 \text { WL } \\
4900467 \text { (Mich. } \\
\text { Ct. App. 2012) } \\
\text { (per curiam) }\end{array}$ & $\begin{array}{l}\text { People v. Younger, } \\
158 \text { N.W.2d } 493 \\
\text { (Mich. 1968) }\end{array}$ \\
\hline Mininesota & $\begin{array}{l}\text { MINN. STAT. ANN. } \\
\text { \$ 611.026; State v. } \\
\text { Rawland, } 199 \\
\text { N.W.2d } 774 \text { (Minn. } \\
1972 \text { ) }\end{array}$ & $\begin{array}{l}\text { State v. Bouwman, } \\
328 \text { N.W.2d } 703 \\
\text { (Minn. 1982) }\end{array}$ & $\begin{array}{l}\text { MNN. STAT. ANN. } \\
\S 609.20\end{array}$ \\
\hline Mississippi & $\begin{array}{l}\text { Groseclose v. State, } \\
\text { 440 So. 2d } 297 \text { (Miss. } \\
\text { 1983) }\end{array}$ & $\begin{array}{l}\text { Stevens v. State, } \\
\text { No. 2000-DP- } \\
00507 \text {-SCT (Miss. } \\
\text { 2001) (en banc) }\end{array}$ & $\begin{array}{l}\text { Miss. CODE ANN. } \\
\S 97-3-17\end{array}$ \\
\hline Missouri & $\begin{array}{l}\text { MO. ANN. STAT. } \\
\S \S 552.030,562.086\end{array}$ & $\begin{array}{l}\text { Mo. ANN. STAT. } \\
\S \S 552.020, \\
552.030 ; \text { State v. } \\
\text { Strubberg, } 616 \\
\text { S.W.2d } 809 \text { (Mo. } \\
\text { 1981) (en banc) }\end{array}$ & $\begin{array}{l}\text { MO. ANN. STAT. } \\
\S \S 565.002,565.023\end{array}$ \\
\hline Montana & $\begin{array}{l}\text { State v. Korell, } 690 \\
\text { P.2d } 992 \text { (Mont. } \\
1984 \text { ) }\end{array}$ & $\begin{array}{l}\text { MONT. CODE ANN. } \\
\S 46-14-102\end{array}$ & $\begin{array}{l}\text { MONT. CODE ANN. } \\
\S 45-5-103\end{array}$ \\
\hline Nebraska & $\begin{array}{l}\text { State v. Hotz, } 795 \\
\text { N.W.2d } 645 \text { (Neb. } \\
2011 \text { ); State v. } \\
\text { Harms, } 650 \text { N.W.2d } \\
481 \text { (Neb. 2002) (per } \\
\text { curiam) }\end{array}$ & $\begin{array}{l}\text { State v. Vosler, } \\
345 \text { N.W.2d } 806 \\
\text { (Neb. 1984) (per } \\
\text { curiam) }\end{array}$ & $\begin{array}{l}\text { NEB. REV. STAT. } \\
\S 28-305\end{array}$ \\
\hline Nevada & $\begin{array}{l}\text { Finger v. State, } \\
27 \text { P.3d } 66(\mathrm{Nev} . \\
2001) \text { (en banc) }\end{array}$ & $\begin{array}{l}\text { Finger v. State, } 27 \\
\text { P.3d } 66 \text { (Nev. } \\
\text { 2001) (en banc) }\end{array}$ & $\begin{array}{l}\text { NEV. REV. STAT. ANN. } \\
\S 200.035\end{array}$ \\
\hline
\end{tabular}




\begin{tabular}{|c|c|c|c|}
\hline JURISDICTION & INSANTTY & MINOE & Prov/EMED \\
\hline New Hampshite & $\begin{array}{l}\text { State v. Fichera, } \\
903 \text { A.2d } 1030 \\
\text { (N.H. 2006) }\end{array}$ & $\begin{array}{l}\text { State v. Gourlay, } \\
802 \text { A.2d } 1203 \\
\text { (N.H. 2002) }\end{array}$ & $\begin{array}{l}\text { N.H. REV. STAT. } \\
\text { ANN. } \S 630: 2\end{array}$ \\
\hline New Jersey & $\begin{array}{l}\text { N.J. STAT. ANN. } \\
\S 2 \mathrm{C}: 4-1 \text { (prior } \\
\text { version held } \\
\text { unconstitutional) }\end{array}$ & $\begin{array}{l}\text { N.J. STAT. ANN. } \\
\S 2 \text { C:4-2 }\end{array}$ & $\begin{array}{l}\text { N.J. STAT. ANN. } \\
\S 2 C: 11-4\end{array}$ \\
\hline New Mexico & $\begin{array}{l}\text { State v. Hartley, } 565 \\
\text { P.2d } 658 \text { (N.M. } \\
\text { 1977); State v. White, } \\
\text { 270 P.2d } 727 \\
\text { (N.M. 1954) }\end{array}$ & $\begin{array}{l}\text { State v. } \\
\text { Balderama, } \\
\text { 2004-NMSC-008, } \\
\text { 135 N.M. } 329,88 \\
\text { P.3d } 845\end{array}$ & $\begin{array}{l}\text { N.M. STAT. ANN. } \\
\S 30-2-5\end{array}$ \\
\hline New York & $\begin{array}{l}\text { N.Y.PENAL LAW } \\
\S 40.15\end{array}$ & $\begin{array}{l}\text { People v. Segal, } \\
429 \text { N.E.2d } 107 \\
\text { (N.Y. 1981) }\end{array}$ & $\begin{array}{l}\text { N.Y. PENAL LAW } \\
\S \S 125.20,125.25\end{array}$ \\
\hline North Carolina & $\begin{array}{l}\text { State v. Humphrey, } \\
196 \text { S.E.2d } 516 \\
\text { (N.C. 1973) }\end{array}$ & $\begin{array}{l}\text { State v. Staten, } \\
616 \text { S.E. } 2 \text { d } 650 \\
\text { (N.C. 2005) }\end{array}$ & $\begin{array}{l}\text { State v. Mathis, } \\
413 \text { S.E.2d } 301 \text { (N.C. } \\
\text { Ct. App. 1992) }\end{array}$ \\
\hline North Dakota & $\begin{array}{l}\text { N.D. CENT. CODE } \\
\text { ANN. } \S 12.1-04.1-01\end{array}$ & $\begin{array}{l}\text { N.D. CENT. CODE } \\
\text { ANN. } \$ 12.1-04.1- \\
01\end{array}$ & $\begin{array}{l}\text { N.D. CENT, CODE } \\
\text { ANN. } § 12.1-16-01\end{array}$ \\
\hline Ohio & $\begin{array}{l}\text { OHIO REV. CODE } \\
\text { ANN. § 2901.01(14); } \\
\text { State v. Staten, 247 } \\
\text { N.E.2d } 293 \text { (Ohio } \\
\text { 1969) }\end{array}$ & $\begin{array}{l}\text { State v. Curry, } 543 \\
\text { N.E.2d } 1228 \\
\text { (Ohio 1989) }\end{array}$ & $\begin{array}{l}\text { OHIO REV. CODE ANN. } \\
\S 2903.03\end{array}$ \\
\hline Oklahoma & $\begin{array}{l}\text { OKLA. STAT. ANN. } \\
\text { tit. } 21, \S 152\end{array}$ & $\begin{array}{l}\text { Jones v. State, } 648 \\
\text { P.2d } 1251 \text { (Okla. } \\
\text { Crim. App. 1982) }\end{array}$ & $\begin{array}{l}\text { OKLA. STAT. ANN. tit. } \\
21, \S 731\end{array}$ \\
\hline Oregon & $\begin{array}{l}\text { OR. REV. STAT. } \\
\S 161.295\end{array}$ & $\begin{array}{l}\text { OR. REV. STAT. } \\
\S 161.300 ; \text { State } \\
\text { v. Nebert, } 260 \\
\text { P.3d 559 (Or. Ct. } \\
\text { App. 2011) }\end{array}$ & $\begin{array}{l}\text { OR. REV. STAT. } \\
\S \S 163.118,163.135\end{array}$ \\
\hline Pennsylvania & $\begin{array}{l}18 \text { PA. CONS. STAT. } \\
\text { ANN. } \S 315\end{array}$ & $\begin{array}{l}\text { Commonwealth v. } \\
\text { Spotz, 47 A.3d } 63 \\
\text { (Pa. 2012) }\end{array}$ & $\begin{array}{l}18 \text { PA. CONS. STAT. } \\
\text { ANN. } \S 2503\end{array}$ \\
\hline Rhode Island & $\begin{array}{l}\text { State v. Johnson, } \\
399 \text { A.2d } 469 \text { (R.I. } \\
\text { 1979) }\end{array}$ & $\begin{array}{l}\text { State v. Amazeen, } \\
526 \text { A.2d } 1268 \\
\text { (R.I. 1987) }\end{array}$ & $\begin{array}{l}\text { State v. Lillibridge, } \\
454 \text { A.2d } 237 \text { (R.I. } \\
1982 \text { ) }\end{array}$ \\
\hline South Carolina & $\begin{array}{l}\text { S.C. CODE ANN. } \\
\S 17-24-10\end{array}$ & $\begin{array}{l}\text { Gill v. State, } 552 \\
\text { S.E.2d } 26 \text { (S.C. } \\
2001 \text { ) }\end{array}$ & $\begin{array}{l}\text { State v. Cole, } 525 \\
\text { S.E.2d } 511 \text { (S.C. } \\
2000 \text { ) }\end{array}$ \\
\hline South Dakota & $\begin{array}{l}\text { S.D. CODIFIED LAWS } \\
\S 22-1-2\end{array}$ & $\begin{array}{l}\text { State v. Schouten, } \\
2005 \text { SD } 122,707 \\
\text { N.W.2d } 820\end{array}$ & $\begin{array}{l}\text { S.D. CODIFIED LAWS } \\
\S 22-16-31\end{array}$ \\
\hline Tennessee & $\begin{array}{l}\text { TENN. CODE ANN. } \\
\S 39-11-501\end{array}$ & $\begin{array}{l}\text { State v. Ferrell, } \\
277 \text { S.W.3d } 372 \\
\text { (Tenn. } 2009 \text { ) }\end{array}$ & $\begin{array}{l}\text { TENN. CODE ANN. } \\
\S 39-13-211\end{array}$ \\
\hline
\end{tabular}




\begin{tabular}{|c|c|c|c|}
\hline JURISDICTION & INSANITY & $\mathrm{MINOE}$ & Prov/EMED \\
\hline Texas & $\begin{array}{l}\text { TEX. PENAL CODE } \\
\text { ANN. } \S 8.01\end{array}$ & $\begin{array}{l}\text { Ruffin v. State, } \\
270 \text { S.W.3d } 586 \\
\text { (Tex. Crim. App. } \\
\text { 2008) }\end{array}$ & $\begin{array}{l}\text { TEX. PENAL CODE } \\
\text { ANN. } § 19.02\end{array}$ \\
\hline Utah & $\begin{array}{l}\text { UTAH CODE ANN. } \\
\S 76-2-305\end{array}$ & $\begin{array}{l}\text { UTAH CODE ANN. } \\
\S 76-2-305\end{array}$ & $\begin{array}{l}\text { UTAH CODE ANN. } \\
\S 76-5-205.5\end{array}$ \\
\hline Vermont & $\begin{array}{l}\text { VT. STAT. ANN. tit. } \\
13, \S 4801 \text { (amended) }\end{array}$ & $\begin{array}{l}\text { State v. Messier, } \\
497 \text { A.2d } 740 \text { (Vt. } \\
\text { 1985) }\end{array}$ & $\begin{array}{l}\text { State v. Hatcher, } 706 \\
\text { A.2d } 429 \text { (Vt. 1997) }\end{array}$ \\
\hline Virginia & $\begin{array}{l}\text { Price v. } \\
\text { Commonwealth, } \\
323 \text { S.E.2d 106 (Va. } \\
\text { 1984); Herbin v. } \\
\text { Commonwealth, } 503 \\
\text { S.E.2d 226 (Va. Ct. } \\
\text { App. 1998) } \\
\end{array}$ & $\begin{array}{l}\text { Bowling v. } \\
\text { Commonwealth, } \\
403 \text { S.E.2d } 375 \\
\text { (Va. Ct. App. } \\
\text { 1991) }\end{array}$ & $\begin{array}{l}\text { King v. } \\
\text { Commonwealth, } \\
4 \text { Va. (2 Va. Cas.) } 78 \\
(1817)\end{array}$ \\
\hline Washington & $\begin{array}{l}\text { WASH. REV. CODE } \\
\text { ANN. } \S 9 A .12 .010\end{array}$ & $\begin{array}{l}\text { State v. Lewis, } \\
159 \text { Wash. App. } \\
1042 \text { (2011) }\end{array}$ & $\begin{array}{l}\text { State v. Fredrick, } 579 \\
\text { P.2d } 390 \text { (Wash. Ct. } \\
\text { App. 1978) }\end{array}$ \\
\hline West Virginia & $\begin{array}{l}\text { State v. Parsons, } 381 \\
\text { S.E.2d } 246 \text { (W. Va. } \\
\text { 1989) (per curiam); } \\
\text { State v. Samples, } \\
328 \text { S.E.2d 191 } \\
\text { (W. Va. 1985) }\end{array}$ & $\begin{array}{l}\text { State v. Joseph, } \\
590 \text { S.E.2d } 718 \\
\text { (W. Va. 2003) }\end{array}$ & $\begin{array}{l}\text { W. VA. CODE } \\
\S 61-2-4 ; \text { State v. } \\
\text { Beegle, } 425 \text { S.E.2d } \\
823 \text { (W. Va. 1992) } \\
\text { (per curiam) }\end{array}$ \\
\hline Wisconsin & $\begin{array}{l}\text { WIS. STAT. ANN. } \\
\$ 971.15 \text {; State v. } \\
\text { Esser, } 115 \text { N.W.2d } \\
505 \text { (Wis. 1962) }\end{array}$ & $\begin{array}{l}\text { State v. Vega, } 206 \\
\text { Wis. } 2 \text { d } 676 \text { (Wis. } \\
\text { Ct. App. 1996) }\end{array}$ & $\begin{array}{l}\text { WIS. STAT. ANN. } \\
\S \S 939.44,940.01\end{array}$ \\
\hline Wyoming & $\begin{array}{l}\text { WYO. STAT. ANN. } \\
\S 7-11-304\end{array}$ & $\begin{array}{l}\text { Dean v. State, } 668 \\
\text { P.2d } 639 \text { (Wyo. } \\
\text { 1983) }\end{array}$ & $\begin{array}{l}\text { WYO. STAT. ANN. } \\
\S 6-2-105\end{array}$ \\
\hline & 18 U.S.C. $\$ 17$ & $\begin{array}{l}\text { U.S. v. Pohlot, } \\
827 \text { F.2d } 889 \\
\text { (1987) }\end{array}$ & 18 U.S.C. $\S 1112$ \\
\hline
\end{tabular}

